\title{
DETERMINATION OF THE APPLICABILITY OF ROBOTICS IN ANIMAL HUSBANDRY
}

\author{
E.A. Skvortsov, O.A. Bykova, V.S. Mymrin, E.G. Skvortsova, O.P. Neverova, V.I. Nabokov \\ Federal State Budget Educational Institution of Higher Education "Ural State Agrarian University" \\ Ekaterinburg, Karla Liebknechta str., 42 \\ Kosilov V.I. \\ Federal State Budget Educational Institution of Higher Education « Orenburg State Agrarian University »
}

\begin{abstract}
Robotization in agriculture must be carried out taking into account various factors. Agricultural organizations are in different conditions, therefore, just economic efficiency is not enough to justify the implementation of robotics. Timeliness of the research topic is conditioned by the need to assess the applicability of implementing robotics at the micro level, taking into account various factors, since this issue has not been sufficiently studied. The article proposes a methodology for a comprehensive assessment of the expediency of robotization of agricultural organizations, taking into account the technical, technological, organizational and social factors characterizing a certain production process. It is proposed, to determine the economic efficiency of the robotics implementation at the first stage of such an assessment. Then the expert group determines the average and relative evaluation of the significance of each factor from the proposed ones. The preliminary selection is completed by assigning the ranks of the preference for implementing robotics to workplaces. The methodology for determining the expedience of robotics has been tested in agricultural organizations at workplaces in animal husbandry.

Using the methodology will increase the validity of decisions on the implementation of robotics in agricultural organizations.
\end{abstract}

Keywords: robotization, agricultural robotics, expediency of robotics, technological unemployment, animal husbandry, cattle breeding.

\section{INTRODUCTION}

The question of the expediency of using robotics in production is one of the most discussed in the economics literature.

Some studies report that as a result of the implementation of digital technology, a huge mass of people will lose jobs - in the race between machines and people, the final choice will be made in favor of robotics [1], which in turn will lead to unprecedentedly high technological unemployment [2]. It is said that it is necessary to be ready for the complete disappearance of a multitude of not only small- or medium- but also highlyskilled jobs, while the speed of technological changes will be so high that workers simply can not physically be retrained to new specialties, continuously replenishing army of unemployed [3].

According to the accurate expression of D.Autora and E.Salomons, humanity soon awaits the "Robocalipsis" in the labor market [4]. At the same time, the shortage of personnel places agricultural organizations in front of the need to apply various labor-saving technologies in animal husbandry [5]. Already, the implementation of robotics in the agricultural organizations has affected a wide range of processes. Examples of the robotics using in agriculture can serve robots in the livestock products production in milking cows, cleaning manure, preparing feeds, etc. [6]. In addition, plant cultivation creates and implements robotics to control weeds, harvesting, processing crops, monitoring crops, etc.

However, experience shows that experts tend to greatly exaggerate the speed of the spread of new technologies and the expedience of its application in agriculture. In addition, a number of researchers have identified a positive relationship between the implementation of innovations in the organizations and increased employment [7]. 
Many studies speak mainly about the technical possibility of robotization in various industries, but not about its expediency [8]. Until now, there is no consensus on the expedience of implementing micro-level robotics and its impact on employment and efficiency $[9,10]$, which determines the relevance of the study.

In the practice of agricultural organizations may be the task of choosing a particular process, while it is necessary to assess the expediency of its robotization. This raises the need to develop a consultative methodology, taking into account the evaluation of the significance of a complex of factors.

The aim of the research is the development and testing of methods for determining the expediency of robotization in agricultural organizations.

\section{METHODOLOGY OF DETERMINING THE EXPEDIENCE OF ROBOTICS IMPLEMENTATION.}

In accordance with the goal, we consider it necessary to propose a methodics for determining the aexpediency of the robotization of an object in accordance with the rank of preference, based on a complex evaluation of a certain process.

The methodology is a comprehensive assessment of technical, technological, organizational and social factors that characterize a certain process performed in an agricultural organization. Factors of integrated assessment, causing the need for the use of a particular equipment, including robotics, in agriculture, can be as follows:

- the amount of costs for the purchase of equipment, taking into account the possibility of obtaining financial support from authorities;

- safety in harmful and dangerous types of work, reduction of occupational diseases and injuries at work;

- the content and attractiveness of labor when using the implemented technics;

- reduction of the need in personnel and the possibility of attracting young professionals;

- improving the quality of products (processes) by reducing the impact on production of personnel risks, performing operations with low variability, high accuracy and in accordance with established technological requirements;

- increase in labor productivity when using this technique;

- the possibility of implementing technics with minimal additional costs for the reconstruction and repair of premises;

- the possibility of adapting the used livestock of animals and species of used plants;

- the availability of personnel trained for operation and maintenance of equipment;

- market opportunity for acquiring equipment for technological operation (process);

- availability of service and the possibility of obtaining technical support in a short time in the abnormal situations;

- degree of staff support of the implementation of technics.

It should be noted that a set of factors can be adjusted based on the conditions of a particular production.

The difficulty in evaluating of alternative variants of engineering is that managers and specialists of agricultural organizations often do not have sufficient information about the robots that are implemented and 
its advantages over traditional production technologies. As the main indicator of economic efficiency of the robotics implementation, we propose to use the expected annual economic effect calculated in accordance with the methodology proposed below. The positive value of the expected annual economic effect testifies to the economic expedience of the robotics implementation, which is a positive result of the feasibility study of the previously selected objects. The feasibility study should be completed by excluding objects that do not have a positive result of the justification.

If the process has been selected at both stages, then it is advisable to implement robotics. However, if there are hazardous to life and harmful to health conditions of work, it is advisable to implement robotics regardless of the passage of the second stage. If the organization has several processes in which it is desirable to implement robotics, pre-selection should be completed by compiling a ranked list of pre-selected robotics processes.

To assess this methodology, it is advisable to involve managers and key specialists of the agricultural organization or experts from outside organizations (Table 1).

Tab. 1. The recommended structure of the expert group

\begin{tabular}{|l|c|}
\hline \multicolumn{1}{|c|}{ The experts } & $\begin{array}{c}\text { Number of specialists } \\
\text { in the group, people. }\end{array}$ \\
\hline Head of the organization & 1 \\
\hline Chief livestock specialist, zootechnicians of all directions & $1-3$ \\
\hline $\begin{array}{l}\text { The main agronomist, agronomists of all specializations (agronomist-seed } \\
\text { grower, agronomist-potato grower, agrochemist, agronomist-horticulturist) }\end{array}$ & $1-3$ \\
\hline $\begin{array}{l}\text { Chief engineer, mechanization engineer for labor-intensive processes and } \\
\text { other specialists of the engineering department }\end{array}$ & $1-3$ \\
\hline The chief economist of the organization & 1 \\
\hline
\end{tabular}

In the processes that showed the best result in the application of the technique of determining the expedience of the use of technology, it is possible to implement robotics in accordance with the rank of preference.

The choice of objects for the robotics implementation was considered with reference to the a milking robot implementation, a robot for the removal of manure and a robot for trimming feeds. For a comprehensive assessment of the expediency of implementing robotics, was created an expert group of five people (Table 2). 
Tab. 2. The list and determination of the importance of the expediency factors for the robotics implementation

\begin{tabular}{|c|c|c|c|c|c|c|c|}
\hline \multirow{2}{*}{ Factors of integrated assessment of production } & \multicolumn{5}{|c|}{$\begin{array}{l}\text { Evaluation of the factor importance, } f \mathrm{i}, \\
\text { points ( } 1 \mathrm{st}-5 \text { th - specialists) }\end{array}$} & \multirow{2}{*}{$\begin{array}{l}\text { The average } \\
\text { value of the } \\
\text { factor } f i\end{array}$} & \multirow{2}{*}{$\begin{array}{c}\text { Relative } \\
\text { assessment of } \\
\text { the factor } \\
\text { importance } Z\end{array}$} \\
\hline & 1-st & 2-nd & 3-d & 4-th & 5-th & & \\
\hline $\begin{array}{l}\text { 1. The amount of costs for the equipment purchase, taking into account the } \\
\text { possibility of obtaining financial support from the authorities }\end{array}$ & 6 & 5 & 5 & 6 & 6 & 5,6 & 0,061 \\
\hline $\begin{array}{l}\text { 2. Safety in harmful and dangerous types of work, reduction of occupational } \\
\text { diseases and injuries at work }\end{array}$ & 8 & 8 & 9 & 9 & 10 & 8,8 & 0,096 \\
\hline $\begin{array}{l}\text { 3. The content and attractiveness of labor when using the implemented } \\
\text { technics }\end{array}$ & 8 & 8 & 8 & 8 & 8 & 8,0 & 0,087 \\
\hline $\begin{array}{l}\text { 4. Reducing the need for staff and the possibility of attracting young } \\
\text { specialists }\end{array}$ & 10 & 9 & 10 & 10 & 10 & 9,8 & 0,107 \\
\hline $\begin{array}{l}\text { 5. Improving the quality of products (processes) by reducing the impact on } \\
\text { production of personnel risks, performing operations with low variability, } \\
\text { high accuracy and in accordance with established technological requirements }\end{array}$ & 10 & 10 & 10 & 10 & 10 & 10,0 & 0,109 \\
\hline 6. Increase in labor productivity using this technics & 8 & 8 & 9 & 8 & 9 & 8,4 & 0,091 \\
\hline $\begin{array}{l}\text { 7. The possibility of implementing technics with minimal additional costs for } \\
\text { the reconstruction and repair of premises }\end{array}$ & 6 & 6 & 5 & 7 & 9 & 6,6 & 0,072 \\
\hline 8. Ability to adapt the used livestock of animals and used species of plants & 6 & 6 & 8 & 8 & 7 & 7,0 & 0,076 \\
\hline 9. Availability of stuff trained for operation and maintenance of equipment & 5 & 5 & 6 & 7 & 5 & 5,6 & 0,061 \\
\hline 10. The market opportunity to purchase machinery for a given process & 9 & 9 & 9 & 9 & 9 & 9,0 & 0,098 \\
\hline $\begin{array}{l}\text { 11. Availability of service and the ability to receive technical support in a } \\
\text { short time in case of emergency situations }\end{array}$ & 8 & 7 & 7 & 6 & 8 & 7,2 & 0,078 \\
\hline 12. Degree of staff support for the technicsimplementation & 5 & 6 & 5 & 7 & 7 & 6,0 & 0,065 \\
\hline Total & & & & & 92 & & \\
\hline
\end{tabular}


The objects of integrated assessment are the workplaces of the operator of machine milking, the cattleman.

Further, each expert assesses the impact of each factor on the decision in favor of the robotics

implementation. The results of a comprehensive assessment of workplaces by all experts are filled in accordance with the forms shown in the tables below. Each expert evaluates the workplace regardless of the opinion of the other experts in the group.

The determination of the significance of the integrated assessment factors of agricultural production is proposed to be carried out according to the following procedure:

1. Evaluation of the importance of the factor in favor of including it in the structure of the factors is carried out on a 10-point scale.

2. The average evaluation of the significance of the factor $F_{i}$ is defined as the direct average of the estimates of all experts by the formula:

$$
\mathrm{F}_{\mathrm{i}}=\frac{\sum_{\mathrm{i}=1}^{\mathrm{i}} \mathrm{F}_{\mathrm{i} 1}}{\mathrm{~L}}
$$

$\mathrm{F}_{\mathrm{i} 1}$ - evaluation of the $\mathrm{i}$-th factor by the 1 -st expert on a 10-point scale, points;

$\mathrm{L}$ - number of expert group, people;

$\mathrm{i}-$ serial number of the integrated production assessment factor, $i=1, \ldots L$.

3. Relative evaluation of the significance of the factor $\mathrm{Zi}$ is defined as the ratio of the average evaluation of the significance of each factor to the sum of the average estimates of the significance of all factors using the formula:

$$
\mathrm{Z}_{\mathrm{i}}=\frac{\mathrm{F}_{\mathrm{i}}}{\sum_{\mathrm{i}=1}^{1} \mathrm{~F}_{\mathrm{i}}}
$$

I - number of integrated assessment factors.

\section{TESTING OF THE METHOD OF ROBOTICS EXPEDIENCE IN CATTLE BREEDING.}

The selection included 10 agricultural organizations, which implemented robotics in production in different years.

Testing of a comprehensive assessment of the expedience of implementing new equipment, where there is an alternative to the robotics implementation at various work places in animal husbandry: milking, manuring, trimming feeds (Table 3).

\begin{tabular}{|c|c|c|c|c|}
\hline $\begin{array}{c}\text { Factors of integrated assessment of } \\
\text { production }\end{array}$ & $\begin{array}{c}\text { Relative } \\
\text { assessment } \\
\text { of the factor } \\
\text { importance }\end{array}$ & Milking & $\begin{array}{l}\text { Manure } \\
\text { cleaning }\end{array}$ & Feed trim \\
\hline
\end{tabular}

Tab. 3. Individual integrated assessment of production technologies 


\begin{tabular}{|c|c|c|c|c|}
\hline 1 & 2 & 3 & 4 & 5 \\
\hline $\begin{array}{l}\text { 1. The amount of costs for the purchase of } \\
\text { equipment, taking into account the } \\
\text { possibility of obtaining financial support } \\
\text { from the authorities }\end{array}$ & 0,061 & 5,6 & 5,8 & 6,8 \\
\hline $\begin{array}{l}\text { 2. Safety in harmful and dangerous types of } \\
\text { work, reduction of occupational diseases } \\
\text { and the level of injuries at work }\end{array}$ & 0,096 & 5,8 & 8,2 & 5,0 \\
\hline $\begin{array}{l}\text { 3. The content and attractiveness of labor } \\
\text { when using the implemented technics }\end{array}$ & 0,087 & 7,6 & 7,4 & 6,8 \\
\hline $\begin{array}{l}\text { 4. Reducing the need for staff and the } \\
\text { possibility of attracting young specialists }\end{array}$ & 0,107 & 10,0 & 6,6 & 8,8 \\
\hline $\begin{array}{l}\text { 5. Improving the quality of products } \\
\text { (processes) by reducing the impact on } \\
\text { production of personnel risks, performing } \\
\text { operations with low variability, high } \\
\text { accuracy and in accordance with established } \\
\text { technological requirements }\end{array}$ & 0,109 & 10,0 & 4,6 & 9,0 \\
\hline $\begin{array}{l}\text { 6. Increase in labor productivity using this } \\
\text { technics }\end{array}$ & 0,091 & 9,0 & 3,4 & 6,6 \\
\hline $\begin{array}{l}\text { 7. The possibility of implementing technics } \\
\text { with minimal additional costs for the } \\
\text { reconstruction and repair of premises }\end{array}$ & 0,072 & 5,6 & 5,2 & 6,8 \\
\hline $\begin{array}{l}\text { 8. Ability to adapt the used livestock of } \\
\text { animals and used species of plants }\end{array}$ & 0,076 & 7,0 & 4,4 & 6,0 \\
\hline $\begin{array}{l}\text { 9. Availability of stuff trained for operation } \\
\text { and maintenance of equipment }\end{array}$ & 0,061 & 5,8 & 5,4 & 6,4 \\
\hline $\begin{array}{l}\text { 10. The market opportunity to purchase } \\
\text { machinery for a given process }\end{array}$ & 0,098 & 10,0 & 6,6 & 8,8 \\
\hline $\begin{array}{l}\text { 11. Availability of service and the ability to } \\
\text { receive technical support in a short time in } \\
\text { case of emergency situations }\end{array}$ & 0,078 & 6,8 & 4,8 & 6,4 \\
\hline $\begin{array}{l}\text { 12. Degree of staff support for the } \\
\text { implementation of technics }\end{array}$ & 0,065 & 7,6 & 5,8 & 8,2 \\
\hline $\begin{array}{l}\text { Integrated assessment of the robotics } \\
\text { implementation in the workplace }\end{array}$ & - & 7,824 & 5,730 & 7,232 \\
\hline
\end{tabular}


We recommend to produce an assessment of the degree of influence of the factor on the decision in favor of robotics on a 10-point scale. The expert determines the complex evaluation of the $\mathrm{Q}_{\mathrm{lj}}$ object as the sum of products of measures scores of the influence of each factor on the relative evaluation of its significance by the formula:

$$
\mathrm{Q}_{\mathrm{lj}}=\frac{\sum_{i=1}^{l} \mathrm{~F}_{\mathrm{i}} * \mathrm{Z}_{\mathrm{i}}}{l}
$$

$F_{i}$ - evaluation of the $i$-th factor by the $j$-th expert;

$\mathrm{Z}_{\mathrm{i}}$ - relative assessment of the significance of the factor;

$\mathrm{j}$ - numerical oder of expert, $\mathrm{j}=1, \ldots \mathrm{n}$;

$\mathrm{i}$ - the ordinal number of the complex assessment factor of the object, $\mathrm{i}=1, \ldots 1$.

The preliminary selection is concluded by assigning the ranks of the preference for implementing robotics into workplaces in accordance with Table 4 and compiling a list of pre-selected robotic objects in accordance with the table. Summarize the estimates of workplaces for which the implementation of robotics is planned, and rank the preferences (Table 4).

Taб. 4. Assigning the rank of preference to objects.

\begin{tabular}{|c|c|c|c|}
\hline \multirow{2}{*}{ Group of Experts } & \multicolumn{3}{|c|}{ Complex estimation of object $\mathbf{Q}_{\mathbf{j}}$, points } \\
\cline { 2 - 4 } & Milking & Manure cleaning & Feed trim \\
\hline 1-st & 7,82 & 5,73 & 7,23 \\
\hline 2-nd & 7,45 & 5,61 & 7,05 \\
\hline 3-d & 7,75 & 5,65 & 7,15 \\
\hline 4-th & 7,91 & 5,35 & 7,12 \\
\hline 5-th & 7,78 & 5,71 & 7,21 \\
\hline Total object evaluation & 7,74 & 5,61 & 7,15 \\
\hline Rank of object preference & 1 & 3 & 2 \\
\hline
\end{tabular}

As can be seen from the data in the table, the milking process with the use of robotics receives the highest total score. According to the expert group, it is necessary to implement robotics taking into account all available factors. The final evaluation should be defined as the arithmetic mean of its estimates by specialists, using the formula: 


$$
\mathrm{Q}_{\mathrm{j}}=\frac{\sum_{\mathrm{j}=1}^{\mathrm{n}} \mathrm{Q}_{\mathrm{lj}}}{n}
$$

The ranks of objects are denoted by the numbers of the natural series from 1 to $m$, where $m$ is the number of evaluated objects.

At the same time, the smallest rank is assigned to the workplace with a larger final score (table 5).

Tab. 5. Ranks of the preference for robotization processes.

\begin{tabular}{|l|c|c|}
\hline \multicolumn{1}{|c|}{ Workplace (object of robotization) } & $\begin{array}{c}\text { Final score of the object } \mathbf{Q}_{\mathbf{j}}, \\
\text { points }\end{array}$ & Rank of object preference \\
\hline Milking & 7,74 & 1 \\
\hline Manure cleaning & 5,61 & 3 \\
\hline Feed trim & 7,15 & 2 \\
\hline
\end{tabular}

As can be seen from the table, based on the results of a comprehensive assessment of the robotics implementation to the workplace, milking has the highest rank of preference from 7.74 points, on the second place is the feed trim from 7.15 points, the third place is taken by manure removal from 5.61 points. Based on the results of the integrated assessment, the specialists and the head of the organization make a decision on the implementation of milking robotics and a feeder subcategory. It was customary to postpone the implementation of robotics for the cleaning of manure, since for a number of reasons its implementation is currently not practical.

The calculation of the expediency of robotics is necessary in order to increase the validity of decisions on the appropriateness of investing in an object taking into account various factors.

\section{SUMMARY}

This research allows to formulate the factors for a comprehensive assessment of the robotization of the production process in livestock. It was developed and tested a methodology for the integrated assessment of the expedience of implementing robotics in agricultural organizations, including the accounting of technical, technological, organizational and social factors characterizing a certain process performed in an agricultural organization. Its use makes possible to increase the validity of decisions on the expediency of implementing this technics in agricultural organizations.

\section{CONCLUSION}

Thus, the use of the methodology makes it possible to take into account the various factors that arise at the microlevel in justifying the expediency of robotization in agriculture.

The advantage of the methodology is the possibility of using managers and specialists of agricultural organizations with scientific justification for the selection and use of robotics in livestock.

\section{CONFLICT OF INTEREST}

The authors confirm that the presented data do not contain a conflict of interest.

\section{GRATITUDES}


The work was prepared with the support of the Ural State Agrarian University.

\section{REFERENCES}

Brynjolfsson E., McAfee A. (2014). The second machine age: Work, progress, and prosperity in a time of brilliant technologies. New York: WW Norton \& Company.

Frey C., Osborne M. (2013). The future of employment: How susceptible are jobs to computerisation? (Oxford Martin School Working Paper). Oxford: University of Oxford.

Ford M. (2015). Rise of the robots: Technology and the threat of a jobless future. New York: Basic Books. Autor D., Salomons A. (2017). Robocalypse now - Does productivity growth threaten employment? Paper presented at the NBER conference in Toronto, 13-14 September, http://conference.nber.org/confer//2017/AIf17/Autor.pdf

Akimov A. Demographic explosion, aging of the population and labor-saving technologies: interaction in the XXI century. / A. Akimov // World Economy and International Relations. 2016. Vol. 60. Vyp. 5. P. 50-60.

Skvortsov E.A. The application of milking robotics in the region [Text] / E.A. Skvortsov, E.G. Skvortsova, V.I. Nabokov, P.S. Krivonogov // The Economy of the Region. 2017. T. 13, Issue. 1. P. 249-260

7.Cortes G. M., Salvatori A. (2015). Task specialization within establishments and the decline of routine employment. Unpublished manuscript, University of Manchester.

Arntz M., Gregory T., Zierahn U. (2016). The risk of automation for jobs in OECD countries: A comparative analysis. Paris: OECD Publishing. OECD Social, Employment and Migration Working Paper, No. 189.

Kapelushnikov R.I. Technological progress is a devourer of jobs? [Text] / R.I. Kapelyushnikov // Issues of Economics. - 2017. - No. 11. - P. 111-140.

Zemtsov S.P. Robots and potential technological unemployment in the regions of Russia: the experience of studying and preliminary assessments [Text] / S.P. Zemtsov // Issues of Economics. - 2017. - No. 7. - P. 142157. 